\title{
Enkulturasi Nilai-Nilai “Keislaman" dalam Proses Pembelajaran di TK Wihdatul Ummah Kota Makassar
}

\author{
Juwanita Sahid \\ BPPAUD dan Dikmas Sulsel \\ juwanitasahid@gmail.com
}

\begin{abstract}
Early childhood education (PAUD) is a social institution that serves to instill cultural, national, and religious values in children. While the existing literatures on PAUD are more focused on the role of social institutions and formal educational institutions in the formation of children (school environment, learning process and community supporting the process), this article focuses on the process of enculturation in applying "Islamic" values in the learning process at TK Wihdatul Ummah.
\end{abstract}

This study was conducted at TK Wihdatul Ummah. Using ethnographic approach, data was collcted using in-depth interview ansd observation. The study involved ten informants who are varied on the basis of age (between 27 and 69 years), and status, consisting of a school principals, three teachers, five parents and a student' guardian.

The study shows that TK Wihdatul Ummah has succeeded in carrying out Wahdah Islamiyah's main mission in the field of education, mainly in developing young generation from an early age by fostering faith (aqidah), monotheism (tauhid), faith (iman) and good deeds (amal sholeh). Character building based on "Islamic" values is the main orientation that is encultured by TK Wihdatul Ummah to early childhood and still refers to the PAUD National Curriculum. TK Wihdatul Ummah has been able to transmit an "Islamic" curriculum that focuses on two core competencies, namely to love the Qur'an and the Hadith and practice Islamic values as the character of pious children. Achievement of competence to love the Qur'an and the Hadith is shown in basic competency activities, namely: memorizing the surahs in juz 30 and reciting the Hadiths of the Prophet, taddabur Al-Qur'an and Hadith, studying hijaiyyah letters, and knowing practical worship according to the guidance of the Prophet. While the attainment of the "Islamic" values as the character of pious children, is shown by Islamic behaviour in daily life, and Islamic independent behavior. Students' learning achievements at TK Wihdatul Ummah include discipline, independence and self-confidence; trust and closeness to the teacher; able to socialize; able to appreciate and understand others; able to understand rewards and punishment; and able to practice Islamic values as sholeh children character. From the emic point of view based on emic perspective (teachers and parents), the achievement in terms of children character building at TK Wihdatul Ummah focuses on religious values (praying independently and according to guidance, worshiping and remembrancing) and morals values (getting used to behaving well, polite, honest, like to give/help and respect) and social emotional values (independence, self-confidence able to socialize, respect and understand others, control themselves naturally, understand the rules and discipline). By studying at TK Wihdatul Ummah, it is not only students, but also parents show significant changes in their everyday behaviour.

Keywords: PAUD, Enculturation, Achievements, Curriculum, and Islamic Values. 


\section{Pendahuluan}

Pendidikan anak usia dini (PAUD) merupakan sebuah pranata sosial dalam bidang pendidikan yang berfungsi untuk menanamkan nilai budaya, kebangsaan, dan agama kepada anak. Berdasarkan data sejarah, pendidikan anak usia dini (PAUD) pertama kali didirikan oleh Frobel pada tahun 1840 di Jerman. Pendirian ini berlandaskan pemikiran awal, bahwa perkembangan dan pertumbuhan anak dalam lingkup keluarga ternyata belum mampu untuk memberikan pemahaman kepada anak mengenai berbagai norma dan nilai kehidupan di luar ruang lingkup keluarga, kemudian dipengaruhi oleh kemampuan para orangtua sebagai media pendidikan ke anak juga terbatas, sehingga ide ini kemudian tersebar ke berbagai negara. Terkhusus di Indonesia pemikiran ini diadopsi oleh Ki Hajar Dewantara pada tahun 1992 dengan mendirikan Taman Lare (anak) yang berkembang menjadi Taman Indria, kemudian berubah menjadi Taman Kanak-Kanak (TK). Pengembangan PAUD terus berkembang, hingga pada tahun 2011 pemerintah melalui Menteri Pendidikan dan Kebudayaan mendirikan dan mencanangkan Pendidikan Anak Usia Dini (PAUD) di setiap desa, melalui program satu desa satu PAUD. ${ }^{1}$

Pendirian awal PAUD bertujuan untuk menciptakan lembaga pendidikan untuk memberikan perhatian khusus kepada empat unsur holistik integratif dalam perkembangan anak yaitu pendidikan, gizi kesehatan, perlindungan, dan pengasuhan. Namun perubahan dari tujuan awal pendirian PAUD terus terjadi, perubahan itu paling nampak terjadi pada daerah perkotaan. Eksistensi lembaga PAUD memperoleh ruang yang cukup besar ditengah modernisasi masyarakat perkotaan, meningkatnya jumlah kelas menengah terbaru (new middle class) juga turut mendorong pengembangan dan perubahan

\footnotetext{
${ }^{1}$ https://borobudurnews.com/program-satu-desa-satupaud-guna-siapkan-generasi-berkualitas/, diakses tanggal 1 Januari 2020.
}

fungsi PAUD (Seda, 2012:4). Kemudian, faktor lain menurut Jurdi (2015:22) menjelaskan bahwa tumbuhnya industri jasa di pusat perkotaan menempatkan PAUD sebagai instrument utama untuk mengatasi defisitnya peran keluarga dan orangtua dalam pendidikan anak.

Perubahan fungsi PAUD dalam kondisi saat ini telah beragam, berbagai inovasi dilakukan oleh lembaga PAUD untuk menarik perhatian para orangtua anak asuh agar mendaftarkan putra-putri mereka ke lembaga PAUD tersebut. Berdasarkan data yang penulis temukan, berbagai upaya dilakukan yaitu dengan melengkapi fasilitas PAUD, peningkatan SDM, menambahkan berbagai kegiatan diluar lembaga hingga melakukan penambahan pada kurikulum dan capaian pembelajaran di lembaga mereka. Fokus pada artikel ini terkhusus pada lembaga PAUD yang melakukan enkulturasi nilai-nilai "keislaman" dalam kurikulum dan capaian pembelajaran mereka. Salah satu lembaga pendidikan yang merupakan saluran dakwah pertama dari ormas Wahdah Islamiyah sebelum membentuk unit pendidikan lainnya.

TK Wihdatul Ummah sebagai lembaga pendidikan anak, bertujuan untuk memperbaiki pendidikan di Indonesia dengan menciptakan sistem pendidikan yang responsif terhadap perubahan dan tuntutan zaman. Oleh sebab itu lembaga pendidikan yang bekerja dibawah organisasi Wahdah Islamiyah ini sangat serius merancang sistem pendidikan berciri khas islami, yang membedakan dengan berbagai pendidikan formal lain nya. Realisasi sistem pendidikan Wahdah Islamiah yang berciri Islami berbeda dalam tingkat satuan pendidikan. Seluruhnya diselaraskan dengan target atau capaian masing-masing.

Fenomena TK Wihdatul Ummah merupakan perubahan sosial budaya yang terjadi dalam dunia pendidikan, ketika anakanak bukan lagi milik keluarga tetapi milik lembaga pendidikan dan lingkungan. 
Pendidikan sebagai keseluruhan proses dari perkembangan dan adaptasi, mengarah pada proses perubahan budaya, termasuk keterampilan-keterampilan, pengetahuan, sikap, nilai-nilai dan kepercayaan serta pola perilaku tertentu. Antropologi sebagai kerangka acuan dan untuk analisis proses pendidikan, berpotensi mengali studi dan pengaruh proses pendidikan yang dipengaruhi oleh kelas sosial dan struktur masyarakat (Hodges 2011:4).

Berbagai penelitian telah dilakukan berkenaan dengan peran penting lembaga PAUD (Amini 2015; Kurniasari 2015; Hunenengo 2014; Abdullah 2010; dan Rolina 2004). Temuan Amini (2015) menyimpulkan dari sisi pendidikan dan pekerjaaan, orang tua berpotensi terlibat dalam pengasuhan anak. Orang tua dinilai cukup terlibat dalam pengasuhan anak namun perlu ditingkatkan khususnya dalam melatih kemandirian anak dirumah. Penelitian Kurniasari (2015), menemukan pola pembelajaran yang dilakukan oleh orang tua yang memiliki latar belakang sarjana, memproduksi pola demokrasi, sementara anakanak yang dididik oleh orang tua yang belum mencapai derajat sarjana tetap bersifat demokratis, tetapi cenderung permisif. Secara spesifik studi ini memberi penegasan yang kuat pada setting sosio budaya dan pengaruh pendidikan formal yang memproduksi anakanak yang lebih egaliter, demokratis, meskipun ada kesan permisif pada mereka yang berpendidikan menengah orang tuanya. Oleh sebab itu, studi tersebut tidak dalam posisi menjelaskan transformasi kelembagaan pendidikan, melainkan pada proses integrasi nilai-nilai universal pendidikan dengan warisan sosial budaya masyarakat.

Hunenengo (2014) mengindikasikan adanya faktor-faktor yang memengaruhi perkembangan sosial anak di lembaga PAUD, yakni: faktor keluarga (di rumah) dan faktor sosial (diluar rumah). Faktor keluarga sangat ditentukan oleh status atau latar belakang sosial ekonomi keluarga, sementara faktor sosial berkaitan erat dengan pergaulan anak di lingkungan sekolah. Studi Abdullah (2010) menemukan bahwa orientasi nilai-nilai baru telah menjauhkan orang-orang kota dari budaya asal mereka sebagai pusat-pusat kebudayaan. Bentuk baru kesukubangsaan digambarkan dalam beragam kompleks perumahan dalam beragam tipe. Pembentuk dan penentu nilai tidak lagi terletak pada orangtua, tetapi pada institusi-institusi lain di luar keluarga. Determinan pembentukan karakter anak tidak hanya dipengaruhi oleh lingkungan keluarga atau orang tua, tetapi juga teman sebaya, pendidikan dan bahkan pasar.

Sementara literatur yang ada lebih terfokus pada peran lembaga sosial dan lembaga pendidikan formal dalam prose pembentukan karakter anak (lingkungan sekolah, proses pembelajaran dan komunitas penopang proses tersebut), artikel ini menitikberatkan pada proses enkulturasi dalam menerapkan nilai-nilai "keislaman" dalam proses pembelajaran di TK Wihdatul Ummah.

Pembahasan dalam artikel ini akan dimulai dengan membahas tentang sejarah perkembangan TK Wihdatul Ummah. Ini kemudian diikuti dengan pembahasan yang terkait dengan bagaimana nilai-nilai "keislaman" dalam kurikulum dibudayakan (enculturated). Sesi terakhir mendemonstrasikan hasil capaian dari kurikulum tersebut dalam kaitan dengan perilaku anak didik.

\section{Metode Penelitian}

Penelitian ini dilaksanakan di Kota Makassar, sebagai kota terdapat jumlah lembaga pendidikan anak usia dini terbanyak (749 atau $12 \%$ dari total) di Sulawesi Selatan. Penelitian ini dilakukan di TK Wihdatul Ummah Kota Makassar. Lokasi ini dipilih karena TK ini merupakan dakwah pertama yang di kembangkan Wahdah Islamiyah sebagai Organisasi Masyarakat. 
Penelitian ini melibatkan sepuluh orang informan yang bervariasi berdasarkan usia (antara 27 dan 69 tahun); status [yang terdiri atas kepala sekolah (satu orang), guru (tiga orang), orangtua murid (lima orang), nenek/pengasuh pengganti orangtua (satu orang) sebagaimana dijabarkan pada Tabel 1 berikut ini:

\begin{tabular}{|c|l|c|l|}
\hline \multicolumn{4}{|c|}{ Tabel 1. Informan Penelitian } \\
\hline No. & \multicolumn{1}{|c|}{ Nama } & $\begin{array}{c}\text { Umur } \\
\text { (tahun) }\end{array}$ & \multicolumn{1}{|c|}{ Status } \\
\hline 1 & Indah & 40 & $\begin{array}{l}\text { Kepala } \\
\text { Sekolah }\end{array}$ \\
\hline 2 & Fitri & 45 & Guru \\
\hline 3 & Mentari & 40 & Guru \\
\hline 4 & Karin & 51 & Guru \\
\hline 5 & Hasnah & 35 & $\begin{array}{l}\text { Orangtua } \\
\text { murid }\end{array}$ \\
\hline 6 & Bunga & 27 & $\begin{array}{l}\text { Orangtua } \\
\text { murid }\end{array}$ \\
\hline 7 & Citra & 29 & $\begin{array}{l}\text { Orangtua } \\
\text { murid }\end{array}$ \\
\hline 8 & Sari & 32 & $\begin{array}{l}\text { Orang tua } \\
\text { murid }\end{array}$ \\
\hline 9 & Nisa & 30 & $\begin{array}{l}\text { Orang tua } \\
\text { murid }\end{array}$ \\
\hline 10 & Aminah & 69 & $\begin{array}{l}\text { Nenek/ } \\
\text { pengasuh } \\
\text { pengganti } \\
\text { orangtua }\end{array}$ \\
\hline
\end{tabular}

Pengumpulan data dilakukan melalui wawancara mendalam (in-depth interview) dan observasi partisipasi. Wawancara terhadap pengurus yayasan, kepala sekolah dan guru dimaksudkan untuk memperoleh informasi tentang sejarah Wahdah Islamiyah dan lahirnya TK Wihdatul Ummah, strategi serta proses pembelajaran yang diterapkan TK Wihdatul Ummah. Selain itu wawancara juga dilakukan terhadap orang tua/wali untuk mendapatkan data terkait perkembangan dan perubahan anak mereka sebelum, saat, dan setelah menempuh pendidikan di TK Wihdatul Ummah. Observasi partisipasi dilakukan pada seluruh aktivitas atau proses pendidikan anak di pendidikan anak di lembaga PAUD, termasuk melibatkan diri pada beragam kegiatan di TK tersebut, seperti belajar-mengajar di kelas dan di luar kelas. Pelibatan di dalam kelas dilakukan dengan mengikuti aktivitas kelas yang terseleksi (yaitu kelas B3) selama seminggu dan ketika anak berada atau bermain di luar kelas. Kegiatan melibatkan peneliti sebagai guru pendamping di dalam kelas dilakukan untuk mendapatkan setting alamiah kegiatan di dalam kelas dan untuk mengetahui proses pembelajaran dan enkulturasi nilai-nilai kepada anak didik di dalam kelas. Selain itu, interaksi juga dilakukan dengan orang tua saat menunggu anak mereka dan saat kegiatan rutin komite sekolah (seperti gathering), ketika ada pemberian makanan tambahan setiap hari Jum'at, ketika ada seminar yang diadakan oleh komite sekolah, ketika tahzin (kegiatan menyempurnakan/memperbaiki/meningkatkan kualitas tajwid bacaan Al-Qur'an) bersama orang tua, ketika ada pertemuan antara orang tua dan guru, dan ketika ada acara penamatan sekolah.

Analisis data penelitian ini dilakukan melalui melalui tiga tahap: Pertama, melakukan reduksi data. Proses ini diawali dengan mengumpulkan seluruh data primer (transkrip wawancara mendalam dan catatan observasi partisipasi), semua data dari wawancara dan observasi dibaca secara berulang, dilanjutkan dengan menyeleksi data yang relevan. Kedua, melakukan kategorisasi untuk menggelompokkan tema-tema yang sejenis, yakni: eksklusifitas, inklusifitas, stereotip TK Wahdah Islamiyah, pendidikan terintegrasi, kurikulum pembelajaran, reproduksi pembelajaran ramah anak, dan capaian pembelajaran. Ketiga, menginterpretasikan data sesuai temuan-temuan penelitian.

Pengajuan izin penelitian dilakukan sesuai prosedur formal dan informal. Secara formal, surat izin penelitian diurus dengan memenuhi segala berkas persyaratan baik dari BKPMD Provinsi Sulawesi Selatan, Kesabangpol 
Kota Makassar hingga surat ditujukan kepada Dinas Pendidikan Kota Makassar. Pengajuan izin penelitian di TK Wihdatul Ummah mendapat respon yang sangat positif. Pihak kepala sekolah dan guru-guru menerima dengan tangan terbuka, ramah, dan memberikan kemudahan untuk melakukan penelitian di TK Wihdatul Ummah. Wawancara mendalam yang dilakukan kepada guru/ustazah di laksanakan setelah kegiatan belajar dan atas kesepakatan bersama. Secara informal, Kepala Sekolah juga menjembatani saya dengan ketua komite sekolah (orang tua murid). Kepala Sekolah juga memberi ruang mengikuti seluruh aktivitas di TK Wihdatul Ummah, termasuk aktivitas penting yang dilaksanakan di sekolah, seperti seminar parenting, pertemuan orang tua, acara penamatan, dan pengajian rutin. Semua nama yang digunakan adalah nama samaran (pseudonym).

\section{TK Wihdatul Ummah dan PAUD}

Perjalanan awal pendidikan dimulai dengan diperolehnya tanah wakaf yang berlokasi di jalan Abdullah Daeng Sirua, Kota Makassar, lalu menjadi lokasi Masjid Wihdatul Ummah. Hadirnya tanah wakaf dan berdirinya masjid perlahan menjadi tempat berkumpul yang disebut azzabikunal awwalun. Di tempat inilah misi dakwah mengepakkan sayap, dari dakwahdakwah individu menuju dakwah berkelompok dan terorganisir.

Basis perkembangan awal Wahdah Islamiyah di bangun dari dakwah masjid, menarik jamaah, hingga pengadaan kegiatan rutin seperti pengajian. Strategi membangun masjid memang cukup mutahir dalam perkembangan dakwah. Masjid mampu menjadi arena baru, sekaligus menjadi magnet kuat dalam menarik jemaah. Keberhasilan strategi ini kemudian ditularkan dan menjadi stimulus baru munculnya masjid-masjid Wahdah Islamiyah sebagai pusat-pusat dakwah. Hal ini juga menandai progresifitas Wahdah Islamiyah sebagai suatu gerakan.
Pada tahun 1990an (1994-1995) yayasan mulai melirik lingkungan sekitar, diantaranya dengan merangkul anak-anak dalam satu pengajian anak. Setelah melihat perkembangan positif dari berdirinya masjid dan meningkatnya antusias jamaah, misi dakwah perlahan bergerak ke lembaga pendidikan formal. Perkembangan awal lembaga pendidikan belum juga terlepas dari peran masjid. Pendidikan Guru TK (PGTK) dengan level D1 (diploma satu) menjadi pintu awal bagi para kader untuk mengasah kemampuan pengajaran. Selain mengaji, orientasi utamanya adalah pendidikan anak yang berpedoman pada Al-Qur'an dan Sunnah. Usia anak yang disasar adalah antara dua dan tujuh tahun, yang merupakan usia emas dalam perkembangan anak.

Tahun kedua PGTK berjalan, Iulusan pertama hadir. Ketersediaan kader dengan kemampuan mendidik anak saat itu belum sejalan dengan ketersediaan "wadah" atau lembaga pendidikannya. Setelah munculnya angkatan pertama dan bersambut angkatan kedua, pada tahun 1998 Yayasan Fathul Muin resmi berubah menjadi organisasi masyarakat (ormas) Wahdah Islamiyah. Terbentuknya Wahdah Islamiyah semakin kokoh dengan misi pendidikan, secara khusus membentuk Yayasan Pesantren Wahdah Islamiyah (YPWI). Sebagai sebuah yayasan yang mengarah pada pendidikan, Yayasan Pesantren Wahdah Islamiyah membentuk struktur organisasi dan memiliki legalitas hukum, sehingga di tahun itu juga berdiri Taman Kanak-kanan (TK) terpadu Wahdah Islamiyah. Setahun setelah terbentuknya Taman Kanak-kanak (1999), dibuatlah ruangan formal baru untuk pembelajaran. Pada tahun yang sama PGTK mulai meredup dan akhirnya berhenti. Memasuki tahun 2000, TK Wihdatul Ummah pada kelas awal yang hanya terfokus pada TPQ (Taman Pendidikan Al Quran) berupa kegiatan belajar mengaji yang ada awalnya hanya terdiri dari satu kelas dan kemudian mengalami penambahan seiring bertambahnya jumlah 
anak didik. Di sisi lain di tahun yang sama, PGTK yang sebelumnya mengalami kemacetan dicoba untuk dihidupkan kembali dengan marwah baru menjadi Sekolah Tinggi IImu Islam dan Bahasa Arab (STIBA). Perubahan ini adalah langkah serius Wahdah Islamiyah sebagai organisasi yang berfokus pada pendidikan.

Sejarah awal terbentuknya TK Wihdatul Ummah tidak seperti kebanyakan sekolah lain yang secara regulatif memperoleh dukungan dana dari pemerintah. Kemandirian dan independensi yayasan menjadi kekuatan tersendiri dalam pembentukan lembaga pendidikan ini. Dalam upaya meningkatkan kualitas pendidikan, Wahdah Islamiyah selalu melakukan pelatihan secara berkala terhadap pengelola dan tenaga pendidik. Mulai dari mengikuti kegiatan peningkatan kompensi PAUD (diklat berjenjang PAUD), diklat manajemen, seminar lokal dan nasional, dan yang terpenting setiap minggu dilakukan upgrading terhadap pengetahuan agama/melalui tarbiyah dan kajian. Tarbiyah adalah kegiatan pengembangan dan bimbingan agama yang diselenggarakan oleh pihak yayasan secara berjenjang ada materi/kurikulum sendiri dan merupakan persyaratan untuk menjadi guru. Tarbiyah juga merupakan kegiatan terjadwal yang dilakasanakan tiap pekan. Muatan-muatan tarbiyah dan kajian (lebih berfokus sesuai tema tertentu dan diselenggarakan tidak secara rutin) ini dijelaskan oleh guru lebih banyak memberikan bekal bagi tenaga pendidik untuk mentramisikan nilai-nilai "keislaman" kepada anak didik.

Lembaga pendidikan anak usia dini dibawah Yayasan Wahdah Islamiyah dalam perkembangan sejak 2000 sampai sekarang (2019/2020) telah tersebar di banyak daerah baik di Sulawesi Selatan maupun luar Sulawesi. Secara keseluruhan terdapat 112 Lembaga PAUD di seluruh di seluruh Nusantara dan di Kota Makassar sendiri terdapat delapan lembaga PAUD yang baik dibawah yayasan Wihdatul Ummah dan yang diinisiasi oleh Kader-kader Wahdah Islamiyah.

\section{Islam dan Kurikulum Pembelajaran}

Untuk memperbaiki pendidikan di Indonesia diperlukan sistem pendidikan yang responsif terhadap perubahan dan tuntutan zaman dan berdasarkan pada sistem pendidikan dan pola kebijakan yang bersesuaian dengan kondisi Indonesia. Dengan berkosentrasi pada lembaga pendidikan, ini menjadikan Wahdah Islamiyah sangat serius merancang sistem pendidikan. Pembinaan generasi muda dalam doktrin Wahdah Islamiyah identik dengan pembinaan akidah, tauhid, iman dan amal soleh (Jurdi 2007:149)

Enkulturasi pembelajaran berdasarkan kurikulum "keislaman" yang diterapkan di TK Wihdatul Ummah dalam bentuk kurikulum pembelajaran. Rangkaian kegiatan pelaksanaan kurikulum "keislaman" diuraikan berdasarkan dua kompetensi, yakni kompetensi inti (mencintai Al-Qur'an \& Hadits dan mengamalkan nilai-nilai "keislaman" sebagai karakter anak sholeh/ah) yang masing-masing dipadukan dengan kurikulum 2013 PAUD dengan mengacu kepada enam aspek perkembangan anak usia dini, yaitu nilai-nilai agama dan moral (NAM), motorik, kognitif, bahasa, sosio-emosional dan seni; kompetensi dasar (melafalkan surah-surah Al-Qur'an, melafalkan Hadits-hadits Rasulullah, Tadabbur Al-Qur'an dan Hadits, mempelajari huruf hijaiyah, mengenal ibadah praktis sesuai tuntutan Rasulullah, mengenal dan membiasakan adab islami dalam kehidupan sehari-hari, dan memiliki prilaku kemandirian islami, dengan masing-masing indikatornya (lihat Tabel 2). 


\begin{tabular}{|c|c|c|}
\hline \multicolumn{3}{|c|}{ Tabel 2. Kompetensi Kurikulum “Keislaman” } \\
\hline Kompetensi Inti & Kompetensi Dasar & Indikator \\
\hline \multirow{4}{*}{$\begin{array}{l}\text { 1. Mencintai Al-Qur'an dan } \\
\text { Hadits sejak usia dini } \\
\text { (Capaian Perkembangan } \\
\text { meliputi NAM, motorik, } \\
\text { kognitif, bahasa, } \\
\text { sosioemosional dan seni). }\end{array}$} & $\begin{array}{l}\text { - Melafalkan surah-surah } \\
\text { dalam Al-Qur'an. }\end{array}$ & $\begin{array}{l}\text { - Melafalkan surah-surah di Jus } \\
30 . \\
\text { - Melafalkan ayat-ayat pilihan }\end{array}$ \\
\hline & $\begin{array}{l}\text { - Melafalkan Hadits-hadits } \\
\text { Rasulullah. } \\
\text { - Taddabur Al-Qur'an dan } \\
\text { Hadits. }\end{array}$ & $\begin{array}{l}\text { - Melafalkan Hadits adab } \\
\text { islami } \\
\text { - Mendengarkan kisah teladan } \\
\text { para Nabi dan sahabat } \\
\text { Rasulullah dan tuntunan } \\
\text { akhlak mulia. } \\
\end{array}$ \\
\hline & $\begin{array}{l}\text { - Mempelajari huruf } \\
\text { hijaiyyah. }\end{array}$ & - Belajar mengaji \\
\hline & $\begin{array}{l}\text { - Mengenal ibadah praktis } \\
\text { sesuai tuntunan Rasulullah. }\end{array}$ & $\begin{array}{l}\text { - Mengetahui jenis-jenis } \\
\text { ibadah. } \\
\text { - Melafalkan bacaan sholat. } \\
\text { - Mengetahui gerakan sholat. }\end{array}$ \\
\hline \multirow{2}{*}{$\begin{array}{l}\text { 2. Mengamalkan Nilai-nilai } \\
\text { ke-Islam-an sebagai } \\
\text { karakter Anak Sholeh } \\
\text { (Capaian Perkembangan } \\
\text { meliputi NAM, motorik, } \\
\text { kognitif, bahasa, } \\
\text { sosioemosional dan seni). }\end{array}$} & $\begin{array}{l}\text { - Mengenal dan } \\
\text { membiasakan adab islami } \\
\text { dalam kehidupan sehari- } \\
\text { hari. }\end{array}$ & $\begin{array}{l}\text { - Mengetahui adab-adab } \\
\text { keislaman yang baik dan } \\
\text { benar. }\end{array}$ \\
\hline & $\begin{array}{l}\text { - Memiliki perilaku } \\
\text { kemandirian Islami. }\end{array}$ & $\begin{array}{l}\text { - Melakukan ibadah praktis } \\
\text { sejak usia dini. }\end{array}$ \\
\hline
\end{tabular}

Sumber: Buku Panduan Belajar Keislaman KB-TK Terpadu Wihdatul Ummah Makassar (Yayasan Pesantren Wahdah Islamiyah), 2017.

Kompetensi yang diinternalisasikan kepada anak didik terdiri atas kompetensi inti mencakup:

- Mencintai Al-Qur'an dan Hadits dengan kompetensi dasar yang meliputi: melafalkan surah-surah Al-Qur'an, melafalkan Haditshadits Rasulullah, tadabbur Al-Qur'an dan Hadits dan mempelajari huruf hijaiyah, mengenal ibadah praktis sesuai tuntutan Rasulullah, memiliki perilaku kemandirian islami.

- Mengamalkan nilai-nilai "keislaman" sebagai karakter anak sholeh dengan kompetensi dasar yang meliputi mengenal dan membiasakan adab islami dalam kehidupan sehari-hari dan memiliki prilaku kemandirian islami).
Kompetensi kurikulum "keislaman" terdiri dari dua komponen, yakni kompetensi inti dan kompetensi dasar. Kompetensi inti dijabarkan dalam kegiatan-kegiatan kompetensi dasar. Untuk kompetensi inti pertama (mencintai Al-Qur'an dan Hadits), kegiatankegiatan kompetensi dasarmya mencakup: melafalkan surah-surah dalam Al-Qur'an, melafalkan Hadits-hadits Rasulullah, taddabur Al-Qur'an dan Hadits, mempelajari huruf hijaiyyah, dan mengenal ibadah praktis sesuai tuntunan Rasulullah. Sedangkan untuk kompetensi inti kedua (mengamalkan nilai-nilai "keislaman" sebagai karakter anak sholeh) kegiatan kompetensi dasarnya mencakup: mengenal dan membiasakan adab islami dalam kehidupan sehari-hari, dan memiliki perilaku kemandirian Islami.

Untuk mencapai indikator yang telah disebutkan diatas dilakukan dalam kegiatan 
harian. Jadwal harian diawali dengan kegiatan melafalkan surah-surah pendek yang dilakukan pada pukul 08.00-08.30 secara berulang (tiga kali pengulangan), sehingga anak terbiasa mengucapkan dan kemudian mengingatnya secara bertahap. Kemudian dilanjutkan setelah 30 menit sebelum berakhir dilakukan recalling yaitu mengulangi materi yang ingin dilakukan penguatan penguasaan oleh anak didik misalnya berupa hafalan surah, Hadits dan do'a harian. Kegiatan ini biasanya disebut kegiatan penutup yang dilaksanakan pada pukul 11.00 sebelum anak pulang pada pukul 11.30. Sebagai contoh dalam satu semester terdapat enam tema, yang dalam tiap tema dilaksanakan selama 3 pekan. Selama 3 pekan terdiri atas 1-3 surah yang yang dilafalkan sehingga selama 2 semester, anak ditargetkan telah mampu melafalkan sekitar 15 surah dan 1 surah pilihan (Ayat Kursy), yakni Al-Fatihah, An-Naas, AlFalaq, Al-lkhlash, Al-Lahab, An-Nashr, AlKaafirun, Al-Kautsar dan Al-Ma'un, Quraisy dan Al-Fiil, At-Takatsur, Al-Qaari'ah, Al-Aadiyat, Azzalah dan Ayat Kursy. Untuk lebih detail tentang surah berdasarkan tema dan alokasi waktu penerapannya didalam pembelajaran per semester dapat dilihat penjabarannya pada Tabel 3.

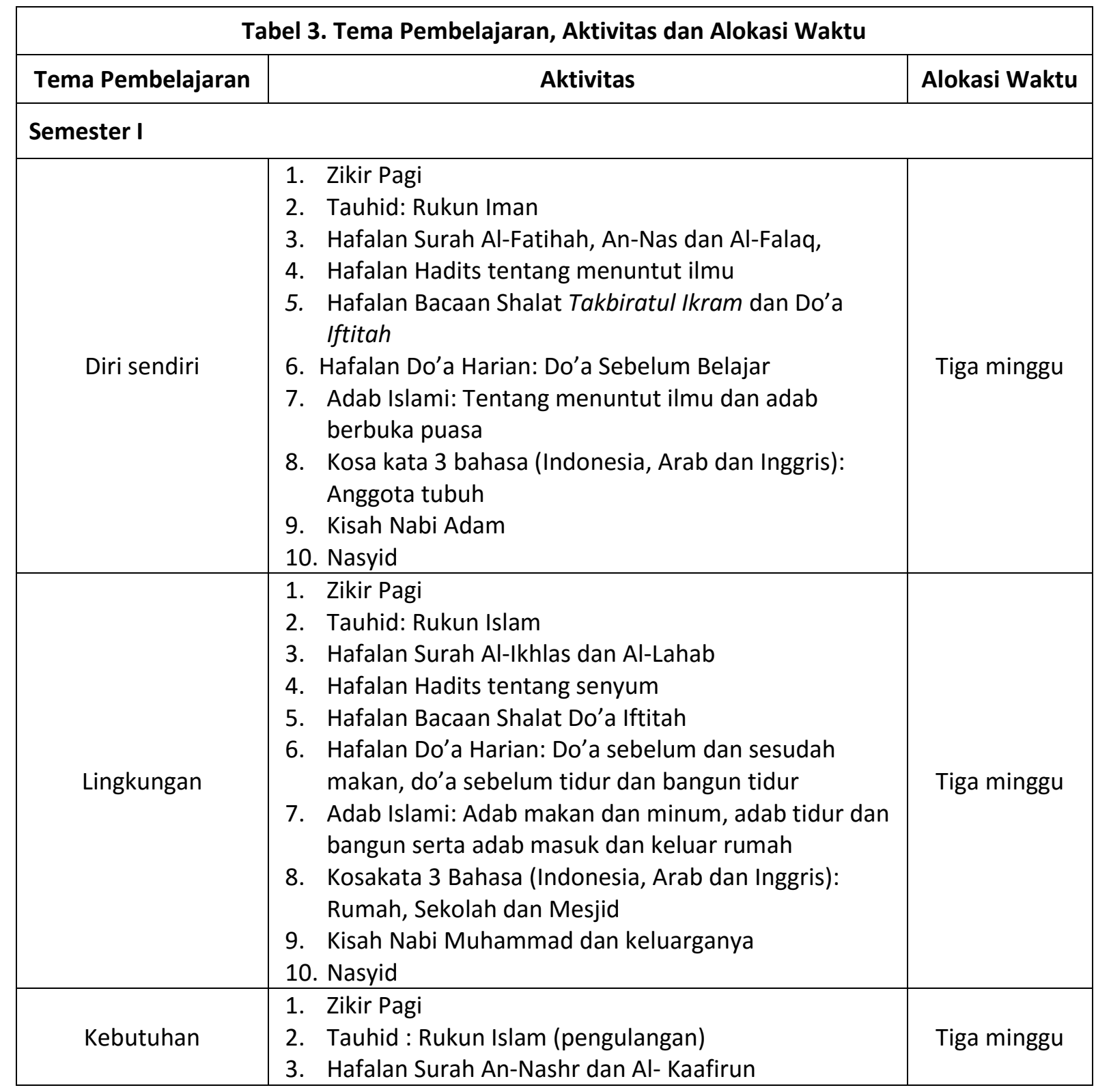




\begin{tabular}{|c|c|c|}
\hline \multicolumn{3}{|c|}{ Tabel 3. Tema Pembelajaran, Aktivitas dan Alokasi Waktu } \\
\hline Tema Pembelajaran & Aktivitas & Alokasi Waktu \\
\hline & $\begin{array}{l}\text { 4. Hafalan Hadits tentang adab makan dan minum dan } \\
\text { Hadits tentang memberi } \\
\text { 5. Hafalan Bacaan Shalat: Do'a ruku dan i'tidal } \\
\text { 6. Hafalan Do'a Harian: Do'a berpakaian } \\
\text { 7. Adab Islami: Adab kepada orang tua dan adab } \\
\text { memakai dan melepaskan pakaian } \\
\text { 8. Kosakata } 3 \text { Bahasa (Indonesia, Arab dan Inggris): } \\
\text { tentang makanan bergizi } \\
\text { 9. Kisah Istri Nabi Muhammad (Aisyah dan Khadijah } \\
\text { 10. Nasyid }\end{array}$ & \\
\hline Binatang & $\begin{array}{l}\text { 1. Zikir Pagi } \\
\text { 2. Tauhid: Rukun Iman (pengulangan) } \\
\text { 3. Hafalan Surah Al-Kautsar dan Al-Ma'un } \\
\text { 4. Hafalan Hadits tentang larangan menyiksa binatang } \\
\text { dan tentang akhlak } \\
\text { 5. Hafalan Bacaan Shalat: Do'a rukuk dan i'tidal } \\
\text { (pengulangan) } \\
\text { 6. Hafalan Do'a Harian: Do'a naik kendaraan } \\
\text { 7. Adab Islami: Adab ketika naik kendaraan dan adab } \\
\text { terhadap binatang } \\
\text { 8. Kosakata } 3 \text { Bahasa (Indonesia, Arab dan Inggris): } \\
\text { tentang binatang } \\
\text { 9. Kisah Nabi Sulaiman Alaihisalam } \\
\text { 10. Nasyid }\end{array}$ & Tiga minggu \\
\hline Tanaman & $\begin{array}{l}\text { 1. Zikir Pagi } \\
\text { 2. Tauhid : Rukun Iman (nama dan tugas malaikat ) } \\
\text { 3. Hafalan Surah Quraisy dan Al-Fill } \\
\text { 4. Hafalan Hadits tentang kebaikan dan berbicara yang } \\
\text { baik/diam } \\
\text { 5. Hafalan Bacaan Shalat: Do'a Duduk diantara } 2 \text { sujud } \\
\text { 6. Hafalan Do'a Harian: Do'a masuk dan keluar WC } \\
\text { 7. Adab Islami: Adab ketika naik masuk dan keluar WC } \\
\text { 8. Kosakata } 3 \text { Bahasa (Indonesia, Arab dan Inggris): } \\
\text { Tentang tanaman } \\
\text { 9. Kisah Abu bakar Ash-Siddiq } \\
\text { 10. Nasyid }\end{array}$ & Tiga minggu \\
\hline \multicolumn{3}{|l|}{ Semester II } \\
\hline Rekreasi & $\begin{array}{l}\text { 1. Zikir Pagi } \\
\text { 2. Tauhid: Zikrullah } \\
\text { 3. Hafalan Surah Al-Humazah dan Al-Ashr } \\
\text { 4. Hafalan Hadits tentang Hadits tentang Keindahan } \\
\text { dan Hadits larangan bertengkar } \\
\text { 5. Hafalan Bacaan Shalat: Do'a Duduk diantara } 2 \text { sujud } \\
\text { 6. Hafalan Do'a Harian: Do'a sebelum dan sesudah } \\
\text { berwudhu } \\
\text { 7. Adab Islami: Adab ketika berwudhu dan adab } \\
\text { terhindar dari syaitan } \\
\text { 8. Kosakata } 3 \text { Bahasa (Indonesia, Arab dan Inggris): }\end{array}$ & Tiga minggu \\
\hline
\end{tabular}


Tabel 3. Tema Pembelajaran, Aktivitas dan Alokasi Waktu

\begin{tabular}{|c|c|c|}
\hline Tema Pembelajaran & Aktivitas & Alokasi Waktu \\
\hline & $\begin{array}{l}\text { tentang tempat rekreasi } \\
\text { 9. Kisah Sahabat Umar Bin Khattab } \\
\text { 10. Nasyid }\end{array}$ & \\
\hline Pekerjaan & $\begin{array}{l}\text { 1. Zikir Pagi } \\
\text { 2. Tauhid: Asmaul Khusnah } \\
\text { 3. Hafalan Surah At-Takasur dan Al-Qariah } \\
\text { 4. Hafalan Hadits tentang Sholat dan Berdo'a } \\
\text { 5. Hafalan Bacaan Shalat: Do'a Tasyahud } \\
\text { 6. Hafalan Do'a Harian: Do'a masuk dan keluar mesjid } \\
\text { 7. Adab Islami: Adab masuk dan keluar masjid } \\
\text { 8. Kosakata } 3 \text { Bahasa (Indonesia, Arab dan Inggris) } \\
\text { tentang pekerjaaan } \\
\text { 9. Kisah Sahabat Utsman Bin Affan } \\
\text { 10. Nasyid }\end{array}$ & Dua minggu \\
\hline Air, udara dan api & $\begin{array}{l}\text { 1. Zikir Pagi } \\
\text { 2. Tauhid: Rukun iman (pengulangan) } \\
\text { 3. Hafalan Surah Al Qariah dan Al-Aadiyat } \\
\text { 4. Hafalan Hadits tentang larangan bernafas di dalam } \\
\text { gelas/bejana dan Hadits Ketika Turun Hujan/ } \\
\text { 5. Hafalan Bacaan Shalat: Do'a Duduk diantara } 2 \text { sujud } \\
\text { 6. Hafalan Do'a Harian: Do'a ketika turun hujan dan } \\
\text { setelah mendengar azan } \\
\text { 7. Adab Islami: Adab ketika turun hujan dan setelah } \\
\text { mendengar azan } \\
\text { 8. Kosakata } 3 \text { Bahasa (Indonesia, Arab dan Inggris): } \\
\text { Tentang air, udara dan api } \\
\text { 9. Kisah Teladan Nabi Nuh, Nabi Musa, dan Nabi } \\
\text { Ibrahim } \\
\text { 10. Nasyid }\end{array}$ & Dua minggu \\
\hline Alat komunikasi & $\begin{array}{l}\text { 1. Zikir Pagi } \\
\text { 2. Tauhid: Menyakini Malaikat Allah } \\
\text { 3. Hafalan Surah Al-Aadiyat } \\
\text { 4. Hafalan Hadits tentang keutamaan mempelajari Al- } \\
\text { Qur'an } \\
\text { 5. Hafalan Bacaan Shalat: Do'a Sebelum Salam } \\
\text { 6. Hafalan Do'a Harian: Do'a ketika turun hujan dan } \\
\text { setelah mendengar azan } \\
\text { 7. Adab Islami: Adab ketika turun hujan dan setelah } \\
\text { mendengar azan } \\
\text { 8. Kosakata } 3 \text { Bahasa (Indonesia, Arab dan Inggris): } \\
\text { Tentang air, udara dan api } \\
\text { 9. Kisah Teladan Nabi Nuh, Nabi Musa, dan Nabi } \\
\text { Ibrahim } \\
\text { 10. Nasyid }\end{array}$ & Dua minggu \\
\hline Tanah airku & $\begin{array}{l}\text { 1. Zikir Pagi } \\
\text { 2. Tauhid: Iman kepada takdir baik dan takdir buruk } \\
\text { 3. Hafalan Surah Az-zalzalah } \\
\text { 4. Hafalan Hadits tentang hak seorang muslim atas }\end{array}$ & Dua minggu \\
\hline
\end{tabular}




\begin{tabular}{|c|c|c|}
\hline \multicolumn{3}{|c|}{ Tabel 3. Tema Pembelajaran, Aktivitas dan Alokasi Waktu } \\
\hline Tema Pembelajaran & Aktivitas & Alokasi Waktu \\
\hline & $\begin{array}{l}\text { muslim lain } \\
\text { 5. Hafalan Bacaan Shalat: Do'a salam dan Do'a zikir } \\
\text { sesudah shalat } \\
\text { 6. Hafalan Do'a Harian: Do'a ditunjukkan kebenaran } \\
\text { 7. Adab Islami: Adab ketika bersin dan adab ketika sakit } \\
\text { 8. Kosakata } 3 \text { Bahasa (Indonesia, Arab dan Inggris): } \\
\text { tentang bendera, Negara dan presiden } \\
\text { 9. Kisah Teladan Nabi Ayyub } \\
\text { 10. Nasyid }\end{array}$ & \\
\hline Alam semesta & $\begin{array}{l}\text { 1. Zikir Pagi } \\
\text { 2. Tauhid: Ma'rifatullah dan berikan kepada hari kiamat } \\
\text { 3. Hafalan Surah Ayat Kursy } \\
\text { 4. Hafalan Hadits hak muslim atas muslim } \\
\text { lainnya(pengulangan) } \\
\text { 5. Hafalan Bacaan Shalat: Do'a salam dan Do'a zikir } \\
\text { sesudah shalat } \\
\text { 6. Hafalan Do'a Harian: Do'a ketika turun hujan dan } \\
\text { setelah mendengar azan } \\
\text { 7. Adab Islami: Adab ketika turun hujan dan setelah } \\
\text { mendengar azan } \\
\text { 8. Kosakata } 3 \text { Bahasa (Indonesia, Arab dan Inggris): } \\
\text { Tentang Alam Semesta } \\
\text { 9. Kisah Teladan dan Dalil dalam Al-Qur'an Surah Ar } \\
\text { rum } 41 \text { dan Surah A'Araf } 56 \text { (Islamic Character } \\
\text { Buliding) } \\
\text { 10. Nasyid }\end{array}$ & Tiga minggu \\
\hline
\end{tabular}

Selanjutnya kompetensi melafalkan HaditsHadits Rasulullah dicapai dengan melafalkan/menghafalkan Hadits-Hadits yang berkaitan dengan adab Islami, yaitu tuntunan/aturan/norma mengenai sopan santun dalam Islam berdasarkan Hadits. HaditsHadits Rasulullah yang dibiasakan kepada anak pada kegiatan harian selama dua semester (lihat tabel 3) mencakup: Hadits tentang menuntut ilmu, tersenyum, berbakti kepada kedua orang tua, adab makan dan minum, larangan menyiksa binatang, akhlak, keindahan, larangan bertengkar, sholat, do'a, Hadits larangan bernafas didalam gelas/bejana, keutamaan mempelajari Al-Qur'an dan hak seorang muslim atas muslim lainnya. Kegiatan melafalkan Hadits juga dilanjutkan dengan dengan menjelaskan makna Hadits dengan memberikan berbagai contoh dalam kehidupan sehari-hari, seperti tata krama terhadap guru, teman, dll.

Tadabbur Al-Qur'an dan Hadits dilakukan melalui kegiatan mendengarkan kisah-kisah teladan Nabi dan para sababat dan bagaimana tuntunan akhlak mulai. Sebagai ilustrasi dapat di lihat pada Tabel $\mathbf{3}$ diatas terkait tema-tema kisah telandan mulai dari Nabi Adam, Nabi Muhammad dan keluarga, Nabi Sulaiman Alaihissalam, Para sahabat Nabi dan Kisah dalam Al-Qur'an. Kegiatan ini lebih banyak menggunakan metode bercerita yang dilakukan ustazah agar menarik minat anak dan setiap ustazah dalam bercerita selalu mengungkapkan hikma/makna dari kisah-kisah tersebut agar anak mudah dalam memahami cerita.

Mempelajari huruf hijaiyah adalah salah satu kompetensi dasar, untuk mencapai kompetensi inti agar anak mencintai Al-Qur'an 
yang secara implementatif dilakukan melalui kegiatan belajar mengaji. Memperkenalkan huruf hijaiyah banyak dipraktekkan di kelas sentra persiapan dan belajar mengaji menggunakan metode Iqra agar anak mudah melafalkan dan menghafalkan surah-surah.

Pengamalan nilai-nilai "keislaman" dilakukan dengan tiga cara: pertama, memperkenalkan ibadah praktis sesuai tuntunan Rasulullah; kedua, mengenal dan membiasakan adab islami dalam kehidupan sehari-hari; dan ketiga, memiliki kemandirian Islami. Memperkenalkan ibadah praktis sesuai tuntunan Rasulullah dilaksanakan melalui kegiatan memperkenalkan kepada anak mengenai jenis-jenis ibadah, pembiasaan melafalkan bacaan sholat, mengetahui gerakan sholat. Sebagai contoh, pelaksanaan sholat dhuha secara berjamaah setiap hari Jum'at. Pelaksanaan praktek sholat dhuha dipimpin oleh salah seorang anak (secara bergiliran) sekaligus membiasakan anak menjadi imam sholat. Kegiatan ini juga untuk mengevaluasi praktek shalat apakah sudah sesuai tuntunan. Selain itu penguatan juga dilakukan setiap minggu ketika anak memasuki sentra ibadah. Aktivitas disentra ibadah dimulai anak dilatih untuk membawa perlengkapan shalat sendiri songkok dan mukenah, membiasakan berwudhu dan berdo'a setelah berwudhu, merapikan shaf dan merapatkan shaf, belajar mengumandangkan azan, melafalkan do'a takbiratul ihram dan do'a iftitah (lihat Tabel $\mathbf{3}$ di atas), membaca surah-surah pendek, melakukan ruku dan i'tidal (bangkit dari ruku) disertai do'a ruku dan i'tidal, melakukan sujud dan melafalkan do'a sujud, melakukan duduk diantara 2 sujud dan melafalkan do'a, melakukan tasyahud (pembacaan tahiyat pada waktu sholat) dan melafalkan do'a tasyahud, membaca do'a sebelum salam dan zikir sesudah shalat.

Mengenal dan membiasakan adab islami dalam kehidupan sehari-hari sebagai tahapan lanjutan setelah anak mampu melafalkan
Hadits, anak kemudian dibekali pengetahuan kognitif tentang adab-adab islam yang baik dan benar sesuai adist yang telah dilafalkan anak.

Sebagai contoh, ustazah menjelaskan tentang adab-adab dalam menuntut ilmu bahwa seorang muslim dalam menuntut ilmu hendaknya ikhlas karena Allah, bersikap sopan terhadap guru, tidak bersikap sombong dengan ilmu yang dimiliki, bersabar dalam menuntut ilmu, bersikap rendah hati dan berusaha mengamalkan ilmu yang sudah dipelajari. Adab islami dalam kehidupan sehari-hari dilakukan dengan mengintegrasikan antara do'a dan adab islami (lihat Tabel $\mathbf{3}$ di atas). Rutinitas kegiatan harian ketika anak datang mencakup: membiasakan mencium tangan, mengucapkan salam, membaca do'a dan zikir pagi, do'a sebelum belajar dan adab dalam menuntut ilmu, do'a dan adab berbuka, do'a dan adab sebelum dan sesudah makan, do'a dan adab sebelum tidur dan bangun tidur, do'a dan adab masuk dan keluar rumah, do'a dan abad terhadap orang tua, do'a dan adab memakai pakaian/melepaskan pakaian, do'a kebaikan dunia dan akhirat, do'a naik kendaraan, do'a duduk diantara 2 sujud, do'a masuk WC, do'a sebelum dan setelah berwudhu, do'a dan adab masuk dan keluar masjid, do'a dan adab ketika turun hujan, do'a setelah mendengar azan dan adab ketika mendengar azan. Selain itu juga terdapat amalan do'a-do'a lainnya, seperti do'a terhadap binatang, do'a kelancaran berbicara dan do'a ditunjukkan kebenaran, do'a mendatangi tempat yang baru, dan adab lain, seperti adab ketika bersin, sakit, dan menjadi hamba yang bersyukur. Memiliki perilaku kemandirian Islami dilakukan melalui upaya melakukaan ibadah praktis sejak usia dini seperti setiap Jum'at kegiatan "keislaman" praktek wudhu, sholat berjamaah, anak-anak bergantian menjadi muadzin, iqomah, dan imam sholat. Selain itu, setelah anak-anak menonton video tentang kisah-kisah akhlak islami/kisah nabi dan sahabat, biasanya anakanak diminta untuk menceritakan kembali 
didepan teman-temannya kisah yang sudah ditonton. Ustazah juga memutarkan video mengenai kisah keteladanan terkait adab sopan santun dan anak-anak diminta memraktekkan bersama-sama di dalam kelas. Adapun aktivitas lainya yang diharapkan anak tidak hanya melakukan disekolah namun di lakukan di rumah. Masing-masing kelas memiliki group orang tua yang biasanya membagikan aktivitas kepada anak, misalnya pada saat Ramadhan, ustazah meminta orang tua untuk memberikan tugas aktivitas ibadah di bulan Ramadhan.

\section{Memadukan Kurikulum Keislaman Dengan Kurikulum 2013 PAUD}

Pembangunan karakter berdasarkan nilai-nilai keislaman menjadi orientasi utama yang diterapkan di TK terpadu Wihdatul Ummah. Untuk menjamin kualitas pembelajaran sesuai dengan standar nasional PAUD, pihak pengelola TK Wihdatul Ummamemadukan kurikulum keislaman dengan kurikulum 2013 PAUD dalam penyelenggaraannya serta menerapkan pengelolaan kelas model sentra. Upaya untuk memadukan sebagaiman sudah dijabarkan pada Tabel $\mathbf{2}$ di atas tentang kompetensi kurikulum keislaman yaitu mencintai Al-Qur'an dan Hadits dan mengamalkan nilai-nilai "keislaman" sebagai karakter anak sholeh, dalam capaiannya menggunakan standar nasional Nasional PAUD berdasarkan Permendikbud No. 137 Tahun 2013.

Berdasarkan Peraturan Menteri Pendidikan dan Kebudayaan Republik Indonesia Nomor 137 Tahun 2013 Tentang Standar Nasional Pendidikan (BAB IV:pasal 10), maka lingkup perkembangan anak sesuai tingkat usia dapat dilihat pada enam aspek perkembangan yang meliputi; aspek agama dan moral, fisikmotorik, kognitif, bahasa, sosial-emosional, dan seni.

Penerapan enam aspek perkembangan ini dilaksanakan dalam kegiatan harian. Mulai dari anak datang dengan kegiatan berbaris dan gerakan senam serta membiasakan mencuci tangan, bermain menggunakan Alat Permainan Edukatif (APE), baik APE luar (melatih motorik kasar) dan menggunakan permainan APE dalam (permainan peran, bola, balok, puzzle dsb), gerak dan nasyid adalah aktivitas untuk melatih aspek fisik-motorik. Melaksanakan shalat, berdo'a dan berzikir, melafalkan dan menghafalkan surah dan Hadits, memberi salam dan menjawab salam, mencium tangan ustazah, berbuat baik dan sopan sebagai kegiatan yang menstimulasi aspek agama dan moral. Ketika anak-anak memasuki sentra persiapan mengenal dan mampu membedakan huruf dan angka, menuliskan nama sendiri pada hasil kerja, mengamati benda dan rasa ingin tahu adalah salah satu kegiatan untuk menstimulasi aspek kognitif. Aktivitas anak bertanya, menjawab pertayaan, bercerita, memahami aturan permainan dalam suatu kegiatan lomba/ permainan merupakan kegiatan yang menstimulasi aspek Bahasa. Adapun aspek sosial emosional antara lain; aktivitas anak memahami aturan dan disiplin (untuk tenang dan mendengarkan nasehat guru) misalnya "siap anak sholeh", menunjukkan kebangaan atas hasil karya sendiri, percaya diri bertanya, mengikuti lomba, mau berbagi/berinfaq, menolong teman, bermain dengan teman, berempati ,memaham orang lain/teman dan meminta maaf kepada teman ketika berbuat salah. Dan Aspek seni berupa aktivitas memainkan alat musik dari peralatan sederhana.

\section{Pengelolaan Kelas Model Sentra}

Ustazah menghadirkan diri sebagai media belajar yang kreatif yang dilakukan dalam pengelolaan kelas yang diimplementasikan dalam kegiatan model sentra. Berdasarkan pedoman pengelolaan kelas yang di terbitkan oleh Direktorat PAUD tahun 2015, ada tiga model pengelolaan kelas yang umumnya di gunakan, yaitu area, sudut dan sentra.

Pengelolaan kelas yang dilaksanakan di TK Wihdatul Ummah pada awal menggunakan 
model area. Namun sejak tahun 2015 diubah menjadi model sentra hingga sekarang. Pelaksanaan model sentra dirasakan oleh para ustazah lebih efektif dalam pembelajaran kerena anak didik secara maksimal memperoleh materi/pembelajaran dari ustazah yang berbeda. Selain itu dengan model sentra memungkinkan adanya fokus capaian di masing-maisng sentra, sehingga anak didik dapat memperkaya khazanah pembelajaran. Selain itu para ustazah juga lebih tertantang untuk aktif dan melakukan kegiatan pembelajaran secara lebih terencana dan kreatif karena setiap sentra membutuhkan persiapan dan penyiapan bahan dalam sebelum anak memasuki sentra-sentra tersebut.

Ciri khas kegiatan kelas model sentra adalah kelas berpindah (moving class) dimana anak-anak bermain dari satu sentra ke sentra lainnya setiap hari. Dalam proses pembelajarannya menggunakan empat pijakan, yaitu pijakan penataan alat (lingkungan), pijakan sebelum main, pijakan selama main, dan pijakan setelah main.

Sentra yang diterapkan oleh TK Wihdatuk Ummah meliputi sentra balok, sentra main peran, sntra persiapan, sentra seni, sentra alam, dan sentra ibadah. Dalam pelaksanaan sentra memiliki penanggungjawab masingmasing dari ustazah dan pendamping. Setiap anak wajib melalui setiap sentra yang ada, sehingga mereka akan mendapatkan berbagai pengetahuan dari masing-masing sentra tersebut, yang meliputi:

Pertama, sentra balok merupakan sentra yang memfasilitasi anak bermain tentang konsep bentuk, ukuran, keterkaitan bentuk, kerapihan, ketelitian, bahasa, dan kreativitas. Kegiatan Bermain di sentra ini sering dikaitkan dengan kegiatan bermain peran yang dilakukan anak. Alat dan bahan Main, antara lain berupa balok-balok dengan berbagai bentuk, balok asesoris untuk main peran, lego berbagai bentuk, kertas dan alat tulis.
Pelaksanaan sentra ini paling ramai dan ribut karena anak-anak asyik memainkan dan menyusun balok, menciptakan kreatifitas, serta mereka bergantian untuk memainkan peran sesuai arahan ustazah, metode ini dianggap paling ideal memperkenalkan nilai-nilai keislaman yang berhubungan dengan kerapihan dan ketelitian. Anak-anak juga diminta untuk menceritakan mengenai balok yang mereka susun, untuk melatih cara berbahasa dari anak didik.

Kedua, sentra main peran terdiri atas Sentra main peran kecil dan sentra main peran besar. Sentra main peran memfasilitasi kemampuan berpikir abstrak, kemampuan berbahasa, sosial-emosional, menyambung pengetahuan yang sudah dimiliki dengan pengetahuan baru menggunakan alat main peran untuk peran kecil (permainan berukuran kecil) dan untuk peran besar (menggunakan ukuran sebenarnya). Secara khusus main peran difokuskan pada upaya pengenalan terhadap lingkungan sosial. Alat dan bahan berupa; berbagai miniatur mainan, berbagai mainan alat rumah tangga, berbagai mainan alat kedokteran, berbagai mainan alat transportasi, dan lain-lain.

Proses pelaksanaan sentra ini dimulai dengan para ustazah menceritakan berbagai kisah-kisah nabi yang berfokus pada kecintaan mereka kepada lingkungan alam, kebijaksanaan dan kebaikan untuk sesama manusia. Setelah menceritakan kisah-kisah tersebut, para ustazah akan meminta mereka mempraktekkan apa yang telah mereka dengarkan ke kehidupan nyata saat ini, sehingga kegiatan ini dapat mendorong sikap positif mereka ketika berinteraksi dengan teman-teman, keluarga, dan masyarakat.

Ketiga, sentra ibadah memperkenalkan kepada anak tentang kehidupan beragama dan keterampilan yang terkait agama yang di anut anak. Sentra juga ini memperkenalkan berbagai atribut agama, sikap dan menghormati agama. Dalam sentra ini mereka juga diminta untuk 
mempraktekkan sholat dengan benar, tepat waktu, dan akidah akhlak berkenaan dengan keagamaan. Pada sentra ini juga mereka diperkenalkan mengenai keberagaman Indonesia, yang memiliki berbagai perbedaan, namun para ustazah berusaha untuk menanamkan jiwa kebersamaan dan saling membantu, meskipun berbeda keyakinan.

Keempat, sentra seni disajikan dalam bentuk seni musik, seni tari ataupun seni kriya/pahat. Pengembangan sentra seni di sesuaikan dengan kemampuan satuan PAUD dan diharapkan mengembangan 2 jenis seni agar mengembangkan kemampuan motorik halus, keselasaran gerak, nada, aspek sosialemosional. Dalam sentra ini para anak didik, diharapkan untuk mampu menciptakan sebuah karya seni, dari tangan mereka sendiri, berbagai karya pun dihasilkan seperti origami, hiasan dinding, mainan karton dan lain nya, mereka diharapka untuk mampu meningkatkan kemampuan gerak motoric melalui pembuatan karya seni tersebut.

Kelima, sentra persiapan lebih menekankan pengenalan keaksaraan awal kepada anak. Sentra ini juga mengembangkan berbagai jenis kegiatan bermain, terutama persiapan bagi kelompok anak usia paling besar yang siap memasuki Sekolah Dasar. Keenam, sentra alam yang sarat dengan pengetahuan sains, matematika, dan seni. Sentra ini diisi dengan berbagai bahan main yang berasal dari alam, seperti air, pasir, bebatuan dan daun. Pengunaan bahan main pada sentra alam memanfaatkan bahan dari lingkungan sekitar dan mengembangkan kreatifitas anak penerapan model ini memungkinkan anak didik di TK Widhatul Ummah mengenal sebagian besar ustazah mereka. Tabel 4 menjabarkan aktivitas harian yang dilaksanakan di Sentra Alam dan Sentra Persiapan:

\begin{tabular}{|c|c|c|}
\hline \multicolumn{3}{|c|}{ Tabel 4. Jadwal Harian (Kelas B) } \\
\hline Jadwal & Aktivitas & Keterangan \\
\hline Pukul $07.00-07.30$ & Penyambutan anak & Oleh guru piket \\
\hline Pukul $07.30-08.30$ & $\begin{array}{l}\text { Berbaris } \\
\text { Zikir Pagi } \\
\text { Do'a harian } \\
\text { Absensi } \\
\text { Hafalan surah dan Hadits }\end{array}$ & $\begin{array}{l}\text { Oleh guru kelas (terdiri } 1 \text { guru inti dan } \\
1 \text { guru pendamping) }\end{array}$ \\
\hline Pukul $08.30-09.10$ & Moving ke ruangan Sentra Alam & $\begin{array}{l}\text { Oleh guru di masing-masing sentra } \\
\text { (terdiri } 1 \text { guru inti dan } 1 \text { guru } \\
\text { pendamping) }\end{array}$ \\
\hline Pukul $09.4-10.15$ & Istirahat /makan bersama & $\begin{array}{l}\text { Bergabung dengan kelas masing dan } \\
\text { makan bersama di ruangan aula }\end{array}$ \\
\hline Pukul 10.15-10.30 & Moving ke ruangan Sentra Persiapan & Oleh guru di masing-masing sentra \\
\hline Pukul $10.30-11.30$ & $\begin{array}{l}\text { Bergabung dengan kelas masing- } \\
\text { masing }\end{array}$ & Oleh guru kelas masing-masing \\
\hline Pukul 11.30 - & $\begin{array}{l}\text { Persiapan Pulang } \\
\text { Menunggu jemputan }\end{array}$ & Oleh Guru piket \\
\hline
\end{tabular}

Jadwal harian anak didik di kelas B3 dimulai pukul 07.30-08.30 (jam pertama diisi dengan aktivitas zikir, doa, hafalan surah-surah). Selanjutnya anak-anak berpindah ke ruangan sentra alam pada pukul 08.30-09.10 kegiatan di
Sentra Alam dengan melakukan kegiatan based on project, menggunakan bahan bekas seperti koran sebagai media belajar. Anak-anak diajarkan membuat bola dari bahan kertas koran, dll. Pada pukul 09.10 bel berbunyi tanda 
jam istirahat bersama dan pada pukul 10.15 aktivitas kembali bergabung pada kelas masingmasing dan bersiap memasuki kelas Sentra Persiapan. Pada Pukul 10.15 anak-anak memulai aktivitas mewarnai abjad dan angka, menuliskan/mencontoh pola huruf dan angka yang telah disediakan. Kegiatan Sentra Persiapan berakhir pada pukul 10.30 dan anakanak bersiap pindah ruangan kembali ke kelas utama (kelas B3), untuk memulai aktivitas yang lain sebelum mempersiapkan diri untuk pulang, dan mereka menunggu jemputan di kelas B3.

Kegiatan sentra tersebut memungkinkan anak didik memeroleh pengalaman belajar yang bervariasi dan lebih menyenangkan, memungkinkan anak memeroleh sumber belajar yang beragam. Selain itu ustazah juga didorong lebih kreatif dan inovatif dalam menciptakan suasana belajar yang menyenangkan untuk anak. Karena sebelum anak memasuki ruangan sentra, ustazah sudah menyiapkan bahan dalam melakukan aktiviatas pembelajaran di masing-masing sentra.

\section{Apa yang Dicapai?}

Pendidikan memberikan pengaruh dan kontribusi yang sangat besar bagi perkembangan diri anak. Pembentukan karakter anak melalui pengembangan sikap moral, agama, sosial dan emosional (Mansur, 2005:92). Pendidikan anak usia dini di TK terpadu Wihdatul Ummah adalah membangun individu yang berkepribadian islami berdasarkan pada pada Al-Qur'an dan AsSunah.

Adapun aspek-aspek capaian pembelajaran yang mengalami perkembangan pada anak usia antara empat dan enam tahun di TK Wihadatul Ummah mencakup: kedisiplinan, kemandirian dan kepercayaan diri; kepercayaan dan kedekatan kepada guru; kemampuan bersosialisasi; kemampuan menghargai dan memahami orang lain; kemampuan memahami penghargaan (reward) dan hukuman (punishment); dan kemampuan mengamalkan nilai-nilai keislaman sebagai karakter anak sholeh(ah).

Kedisiplinan, Kemandirian dan Kepercayaan Diri Kedisiplinan, kemandirian dan kepercayaan diri merupakan fondasi penting dalam pendidikan. Kedisiplinan ditanamkan melalui beragam aktivitas, mulai dari datang tepat waktu, berpakaian sesuai aturan yang ditetapkan, menyimpan sepatu dan tas ditempat yang telah disediakan, mengucapkan salam, mencium tangan guru, berbaris di depan kelas, melafalkan zikir dan do'a, memasuki kelas dengan tertib, mendengarkan guru ketika absensi, hingga duduk dengan rapih dan tertib.

Kemandirian anak ditanamkan melalui berbagai aktivitas disertai dengan motivasi dan arahan dari ustazah, seperti masuk di kelas tanpa diantar/ditunggui oleh orang tua/wali, ke toilet, mencuci tangan dan berwudhu sendiri, membersihkan/merapikan mainan sendiri. Ustazah tidak lagi mendatangi anak-anak, melainkan anak lebih banyak dilatih untuk maju ke depan kelas, guru memotivasi dan mengarahkan anak-anak. Ustazah hanya mememotivasi mereka lebih banyak memotivasi anak

Untuk menumbuhkan rasa percaya diri, anak-anak diajarkan untuk mengemukakan pendapatnya dan menstimulasi mereka untuk bercerita, dan mendorong anak untuk aktif bertanya. Ilustrasi menumbuhkan rasa percaya diri anak dengan mengajak anak secara bergantian memimpin kegiatan. Misalnya pada saat kegiatan melafalkan dan menghafalkan surah dan Hadits serta anak-anak diarahkan untuk banyak bercerita tentang pengalaman atau pendapatnya tentang materi kisah atau tema yang sedang dibahas dalam kegaiatan harian. Anak-anak juga aktif diikutsertakan dan di fasilitasi mengikuti lomba-lomba dengan dibekali pemahaman bahwa mengikuti lomba untuk latihan meningkatkan kepercayaan diri bukan pada upaya untuk memangkan lomba semata. 
Kepercayaan dan Kedekatan Kepada Guru

Kepercayaan dan kedekatan kepada guru salah satu capaian yang diharapkan uztazah agar arahan dan pesan-pesan yang ingin disampaikan dapat diterima secara efektif oleh anak didik. Prinsip kepatuhan dibangun atas dasar kedekatan guru kepada anak. Pada usia 46 tahun secara psikologis, anak telah mampu menjalin kedekatan dengan orang lain selain orangtua, yangdalam konteks sekolah adalah sosok seorang guru. Kedekatan kepada ustazah sebagai pintu masuk bagi pendidik untuk menanamkan nilai-nilai keislaman kepada anak dengan kelembutan dan kesabaran kepada anak didik. Nisa (30 tahun), misalnya, bahwa ketika minggu pertama masuk sekolah, anaknya (Diva) selalu menangis karena tidak mau berpisah dengannya dan tidak mau ditinggalkan di dalam kelas. Namun, ia menyaksikan sendiri bagaimana ustazah dengan kelembutan dan kesabarannya membujuknya hingga secara bertahap Diva dapat teratasi.

Kepercayaan kepada guru merupakan bagian dari pengembangan kemampuan anak pada aspek sosial emosional, yaitu kesadaran diri untuk menumbuhkan kepercayaan pada orang lain. Ibu Mentari (40 tahun), yang pertama-tama yang harus ditanamkan kepada anak didiknya adalah percaya pada dan dekat dengan ustazah. Jika mereka percaya dan dekat dengan ustazah, maka mereka dapat dengan mudah untuk memberikan arahan dan menjelaskan berbagai aturan-aturan yang seharusnya dipatuhi anak di sekolah agar anak dapat berdisiplin.

Kedekatan guru dengan anak didik tidak saja terfokus pada salah seorang atau pada guru kelas saja, tapi anak-anak di TK Wihdatul Ummah mengenal sebagian besar guru yang ada melalui kegiatan sentra. Kegiatan sentra inilah dilakukan dengan konsep "moving class" sehingga anak sejak Senin-Kamis berpindah antar sentra, dari sentra balok kemudian sentra peran, sentra seni, sentra alam dan sentra imtaq (ibadah). Meskipun guru-guru mereka menggunakan cadar, namun anak-anak akan mudah mengenali ustazahnya dari suaranya. Penggunaan cadar dapat lebih fleksibel jika melakukan aktivitas di dalam ruang yang tertutup/tidak ada laki-laki, guru bercadar dapat menanggalkan cadarnya ketika mengajar.

\section{Kemampuan Bersosialisasi}

Salah satu kemampuan yang diharapkan dapat dimiliki adalah kemampuan untuk dapat bersosialisasi dengan baik dengan teman sebaya. Kemampuan anak bersosialisasi akan berimplikasi dengan kemampuan anak untuk dapat memahami orang lain, memahami perasaan temannya dan merespon, berbagi dengan orang lain, menunjukkan kemampuan toleran, dan bersikap kooperatif dengan teman.

Anak-anak yang sebelumnya belum memiliki teman setelah memasuki bulan kedua sudah mampu bersosialisasi dengan teman. Setiap hari di awal pertemuan sudah melakukan simulasi agar anak-anak saling mengenal. Misalnya, mengenalkan anak pada saat absensi/kehadiran sambil berdialog dengan anak lainnya menanyakan kabar sekaligus mengajarkan kepedulian pada teman jika ada diantaranya tidak hadir/berhalangan datang. Berdasarkan pengalaman orang tua (Nisa, 30 Tahun ) bahwa setelah memasuki bulan kedua anaknya (Dinda, Usia 4 Tahun 8 Bulan) sudah memiliki teman bahkan mereka biasanya menjadi betah disekolah karena masih bisa bermain dengan temannya, meskipun waktunya mereka pulang ke rumah. Berdasarkan pengalaman orangtua bahwa anak ketiganya, meskipun sekitar 6 bulan bersekolah di TK Wihdatul Ummah, namun sudah ada perubahan, anak saya sudah bisa berbagi ke temannya, dia selalu menceritakan ketika ada temannya yang tidak membawa makanan.

\section{Menghargai dan Memahami Orang Lain}

Untuk mengarahkan anak menghargai dan memahami orang lain, pembelajaran diarahkan pada penerapan nilai-nilai islami, terutama 
bagaimana adab-adab islami dan disertai dengan pemahaman Hadits-Hadits. Kemampuan anak untuk "menghargai hak orang lain" ini yang masih menjadi tantangan. Pada anak usia dini sesuai karakternya masih memiliki egonya yang cukup besar, jadi tantangan di bulan ketiga adalah bagaimana agar anak-anak belajar menghargai temannya. Inilah yang sedang saya tanamkan kuat ke anakanak didik saya. Kami ajarkan menghargai hasil karya temannya, dan mengajarkan untuk mengetahui haknya (milik) dan "bukan miliknya". Menurut Ustazah Fitri (45 tahun) inilah yang sedang dia terapkan ke anak didiknya, anak sebagian besar sudah mampu menghargai hasil temannya, dan memberi apresiasi dan sudah tidak lagi membawa mainan sekolah pulang ke rumah, anak sudah mengetahui mana yang menjadi haknya/miliknya. Proses mengajarkan anak menghargai hak orang lain ini memang membutuhkan waktu, dan masih terus dia terapkan dan lakukan pembiasaaan kepada anak didiknya.

Hal senada di ungkapkan oleh Mentari (40 tahun) bahwa dari 19 anak didiknya di kelas B.3 sebagian besar (75-80\%) anak telah memiliki kemampuan untuk saling menghargai, selebihnya masih ada anak yang masih tinggi egonya. Sebagai contoh sebagaian besar anak setelah bermain atau menggunakan APE (alat permainan edukatif) biasanya menyimpan dan mengembalikan permainan ketika sudah digunakan, namun masih ada anak yang membawa pulang permainan yang disediakan di sekolah. Begitu pula dengan kegiatan bermain, sebagaian besar dapat bermain bersama menggunakan APE yang disediakan pihak sekolah, meskipun masih ada anak yang belum mau berbagi dan saling memahami.

Upaya yang dilakukan guru menjelaskan tentang adab islami dan sekaligus bercerita kisah teladan. Adapun pesan-pesan yang disampaikan kepada anak misalnya Anak-anak dibiasakan tentang adab berbicara, yaitu bagaimana bertutur kata yang lembut dan sopan kepada orang yang lebih bagaimana bersikap sopan (adab terhadap orang tua dan guru), tidak berteriak atau meninggikan suara karena seburuk-buruk suara adalah suara kekedai dan anak diajarkan menegakkan kejujuran dan tidak mengambil sesuatu yang bukan miliknya, tidak mencela atau mengejek teman serta membiasakan mengucapkan "tabe" kepada siapa saja dan membiasakan memberi salam.

\section{Memahami Tentang Konsep Penghargaan dan "Hukuman"}

Prilaku anak di kelas diapresiasi dalam bentuk penghargaan dan "hukuman" yang bersifat edukatif. Dari segi penghargaan, guru menunjukkannya dalam bentuk ekspresi dan simbol dengan memberikan senyuman dan simbol-simbol, seperti "jempol" atau "bintang" (yang merupakan simbol piala) atas prilaku yang baik (seperti, keaktifan di kelas, berintaq, mampu menyelesaikan hafalan, mematuhi arahan ustazah, duduk tenang dan menyelesaikan tugas/prakarya yang diberikan) . Oleh karenanya, untuk memotivasi mereka, setiap pagi guru akan bertanya: "Apakah anakanak mau dapat piala hari ini?" Ibu Karin, misalnya, mengungkapkan:

\begin{abstract}
Mereka sudah tau kalo saya kasih jempol maka anak-anak mengerti sudah bermakna tindakannya dianggap baik oleh saya, dan akhirnya anak sendiri menilai tindakan yang kurang baik bukan saja tidak diberi "jempol" dan justru anak-anak sendiri tau kalo jempol yang kebawah itu berarti tindakannya kurang baik (Ibu Karin, 45 tahun).
\end{abstract}

Dari segi "hukuman" terhadap prilaku anak yang buruk., seorang guru "menghukum" dengan cara menunjukkan ekspresi ketidaksenangan atas prilaku anak yang tidak baik (seperti mengganggu teman dan tidak mendengar nasehat guru). "Hukuman" juga 
dilakukan dengan menegur. Misalnya, suatu hari dua orang anak sedang mengganggu temannya yang berkebutuhan khusus. Atas kejadian tersebut, ustazah mencoba menegur dan meminta pengertian anak lainnya untuk memahami temannya dengan tidak menggangu karena teman tersebut belum memiliki kemampuan yang sama seperti mereka. Anakanak yang menganggu temannya disuruh mengembalikan "songkok" dan meminta maaf kepada temannya dan ustazah kembali menjelaskan dan memberikan pengertian tentang pentingnya saling memahami. Kejadian yang serupa juga terjadi ketika seorang anak laki-laki menganggu anak perempuan dan ustazah menganjurkan untuk meminta maaf secara langsung kepada teman yang diganggu. "Hukuman" sekaligus penghargaan juga biasanya diberikan pada akhir pembelajaran. Setiap kegiatan penutup sekitar pukul 11.20 biasanya ustazah menyampaikan tentang siapa saja yang hari ini berkelakuan baik dan berhak untuk memperoleh piala atau jempol, dan sekaligus menjelaskan ada anak yang hari ini belum diberikan piala atau jempol karena menganggu temannya. Biasanya, anak pengganggu pulang paling akhir dan dihukum dengan mengucapkan istigfar (astagfirullah) sebanyak mungkin sebelum pulang dan merapikan meja dan kursi ketika temantemannya lainnya sudah diijinkan pulang. Penghargaan dan "hukuman" ini dimaksudkan untuk mengajarkan kepada anak tentang nilainilai yang berkaitan dengan prilaku baik yang harus dihargai dan prilaku buruk yang harus dihindari.

\section{Mengamalkan Nilai-nilai "Keislaman" Sebagai Karakter Anak Sholeh}

Capaian pengamalan nilai-nilai keislaman sebagai karakter anak sholeh meliputi: pertama, anak mampu melafalkan dan menghafalkan bacaan surah, Hadits dan do'a/zikir. Menurut Kepala Sekolah sebagian besar $(80 \%)$ anak mampu menghafalkan surah- surah di Juz 30 sebanyak 20 sampai 30 surah, bahkan $20 \%$ anak telah mampu menghafal 30 surah; kedua, anak berperilaku berdasarkan agama yang dianut, mampu mengerjakan shalat dan berpakaian sesuai agama yang dianut dan menghargai orang lain.

Ini dilakukan dengan kegiatan pembiasaan dalam kegiatan harian diuraikan sebagai berikut:

(1) Pembiasaan sehari berupa pembiasaan mengucapkan dan menjawab salam ustazah saat datang dan pulang serta bersalaman dengan ustazah;

(2) Zikir Pagi hari saat berbaris sebelum masuk kelas;

(3) Do'a sebelum masuk kelas;

(4) Pembiasaan membaca do'a sebelum belajar;

(5) Rutinitas pagi melafalkan dan menghafal surah juz 30, do'a harian, Hadits pilihan dan bacaan sholat;

(6) Pembiasaan membaca do'a sebelum dan setelah makan;

(7) Pembiasaan berdo'a sebelum bermain dengan membaca basmallah

(8) Saat anak akan ke kamar mandi diigatkan membaca do'a sebelum masuk dan keluar kamar mandi;

(9) Pembiasaan pengulangan hafalan saat 30 menit terakhir sebelum pulang dan

(10) Pembiasaan penutup majelis, berdo'a kepada orang tua, do'a kebaikan dunia dan akhirat, do'a keluar rumah, do'a naik kendaraan yang dilaksanakan 30 menit sebelum pulang.

Selain hafalan surah, do'a harian, Hadits pilihan dan bacaan sholat, menurut Ibu Mentari (40 tahun) yang telah sembilan tahun mengabdi di TK Wihdatul Ummah, anak-anak diajarkan akhlak anak sholehah, perkataan bil hikma, berkata-kata yang baik saat sedih dan marah, senantiasa mengucapkan salam saat bertemu dan berpisah, mengucapkan kata-kata syukur, berkata-kata yang baik dan lembut, jika mengetahui teman sakit, mendo'akan dengan 
kata-kata bil hikmah. Jadi anak-anak diajarkan untuk membiasakan diri berakhak sebagai anak sholeh/ah.

Hal senada juga diungkapkan oleh seorang nenek, Ibu Aminah (69 tahun), yang telah memasuki tahun keempat menunggui cucu pertamanya bersekolah di TK Wihdatul Ummah. Ibu Aminah mengungkapkan bahwa cucunya kini telah bagus hafalannya, padahal sebelumnya ia tak tahu apa-apa. Sekarang ia sudah bisa melantunkan azan dan mengikuti lomba terkait, dan bahkan berani menegur jika dewasa berprilaku yang menyimpang dari tata karma islami, seperti berbicara keras, berbicara kotor, dan langsung dibacakan Hadits-nya.

Pengalaman lain dikisahkan o,eh seorang orang tua murid (Ibu Citra, 29 tahun), bahwa sebelum anaknya disekolahkan di TK Wihdatul Ummah, anaknya bersekolah Play Group di salah satu sekolah bergengsi yang anak didiknya sebagian besar adalah orang Tioghoa. Meskipun di awal-awal orientasi anaknya selalu mencari-cari alasan untuk tidak ke sekolah setelah pindah ke TK Wihdatul Ummah, namun berkat ketelatenan, kesabaran dan nilai-nilai yang ditanamkan ustazah, anaknya menunjukkan banyak perubahan, sebagaimana dututurkannya berikut ini:

Dulu putri saya ndak mau sekali disuruh berpakaian muslimah... bergaya hidup mewah, maunya gantiganti sepatu, tas, pakaian, dan ndak mau mengerti meskipun sudah dijelaskan. Pokoknya ndak mau mendengar. Perubahan terjadi setelah penuh perjuangan dalam beradaptasi. Tidak cukup enam bulan di TK Wihdatul Ummah sudah mulai sedikit sabar, tidak lagi minta dibelikan macam-macam... karena disini anak-anak tidak fokus ke style... saya pun dengan papinya jadi lebih dekat dan peduli dengan aktivitas sekolah.

Bahkan kini putrinya juga konsisten mengenakan pakaian Muslimah, dan jika menerima tamu di rumah, ia menggunakan mukena atau jilbab. Putrinya juga semakin disiplin yang ditandai dengan rajin shalat dan tepat waktu, tidak mau telat mengikuti kegiatan zikir pagi dan melaksanakan shalat Dhuha. la juga menjadi lebih sabar, lebih menghargai orang dan selalu bersyukur. Semua perubahan pada putrinya terjadi secara bertahap dan untuk mempertahankannya, setelah tamat TK, putrinya melanjutkan pendidikannya di Sekolah Dasar Wahdah Islamiyah agar apa yang diperolehnya di TK dapat berkelanjutan. Selain perubahan pada diri anaknya, ibu Citra dan suaminya juga menjadi lebih dekat kepada Allah SWT setelah menjadi ketua ketua komite sekolah dan banyak terlibat dalam kegiatan takzim dan tarbiyah, sehingga bukan saja putrinya yang mengalami perubahan, namun sebagai orang tua Citra juga mulai "hijrah" dan mendalami kajian-kajian Islam.

Capaian anak lainnya diungkapkan oleh Ibu Sari, yang berprofesi sebagai dokter dan dosen, yang tiga anaknya sekolah di TK Wihdatul:

Banyak sekali perubahan yang terjadi pada anak-anaknya... semua anak saya sekolahkan di TK Wahdah.... Akhlaknya terutama yang mengalami perubahan, termasuk hafalan AlQur'an, Hadits-Hadits dan do'a-do'a... Kalau saya capek, dia kasihan lihat saya, menawarkan bikin teh atau susu, pijat saya... rebutan semua lakukan.... kalau ketemu temanteman saya, mereka tanpa disuruh langsung mencium tangan (salim), membantu saya urus adiknya yang masih bayi, dan ini bikin saya terharu, anak-anak juga membantu saya mengurus neneknya yang lansia, memapah dan mengaji di sebelahnya... (Ibu Sari, 32 tahun).

Jika merujuk pada kutipan di atas, maka perubahan yang paling signifikan yang dirasakan oleh Ibu Sari sejak anak-anaknya bersekolah di Wihdatul Ummah adalah 
perubahan dari segi akhlak mereka. Selain itu, Ibu Sari juga mulai aktif mengikuti kegiatan tahzin dan tarbiyah untuk belajar lebih jauh tentang ilmu agama.

Contoh-contoh di atas berkelindan dengan apa yang ditegaskan oleh Ibu Indah (43 tahun) bahwa nilai yang menjadi acuan pihak lembaga (TK Wihdatul Ummah) dalam mendidik anak dalam berprilaku adalah akhlakul karimah. Nilai ini mewujud pada capaian pendidikan anak yang khas dari TK Wihdatul Ummah yaitu anak sebagai "polisi moral".

Dalam kaitan anak sebagai "polisi moral", Ibu Indah menekankan bahwa:

Anak-anak itu kami sudah jadi "polisi moral". Misalnya, anak-anak di sekolah diajarkan Hadits dan ayat mengenai adab makan dan minum, terus orangtuanya di hadapan si anak kebetulan minum sambil berdiri. Nah, si anak akan menegur. Itu banyak kasusnya terjadi, subhannallah sekali. Bahkan ada yang langsung bacakan Haditsnya. Wah bisa dibayangkan hebatnya ini yah karena anak-anak memang dilatih untuk menghafal dan membentuk karakternya sesuai ajaran Islam sebagaimana dalam Hadits dan Al-Qur'an (Ibu Indah, 40 tahun).

"Polisi moral" yang dijelaskan Ibu Indah di atas memperjelas bahwa anak-anak sebagai anak didik tidak hanya mampu mengetahui perbuatan yang baik namun juga mampu mengoreksi tindakan orang disekitarnya. Setiap anak memiliki persepsi, konstruksi dan pemaknaan sendiri, sehingga tidak akan sama pada tiap anak didik (Maliki, 2008:240-241). Di beberapa kasus, sikap "polisi moral" di luar ekspektasi orang tua dan guru. Ibu Hasnah (35 tahun), salah seorang orangtua murid, mengatakan bahwa:

Waduh kami sekeluarga sempat kaget waktu itu. Pas kami lagi nonton televisi dan lagi rame bicara-bicara, ada ayahnya ada opanya ada juga tante-tantenya, tiba-tiba dia berteriak sekeras tenaga" "diam sambil berdiri". Semua orang kan jadi kaget, langsung tiba-tiba semua diam, terus ini anak bilang "tidak boleh bicara kalau ada suara adzan, kasi mati juga televisi". Dia bilang "ini ada Haditsnya loh". Akhirnya semua orang diam, televisi juga dikasih mati. Saya sama ayahnya cuman saling tatap dan senyum-senyum (Hasnah, 35 Tahun).

Contoh kasus yang ditunjukkan oleh anak dari Ibu Hasnah (35 tahun), misalnya, mengindikasikan bagaimana capaian pendidikan anaknya (Aulia) di sekolah yang di luar dugaan. Aulia tidak hanya sekedar belajar, menghafal dan menyelesaikan setiap tugas rumah yang diberikan, tetapi mempraktekkan setiap hafalan dan pengetahuannya dalam kehidupan sehari-hari.

Contoh kasus lainnya sebagaimana yang dijelaskan oleh Ibu Bunga (27 tahun) terkait tata krama yang ditunjukkan oleh anaknya saat menegur ayahnya yang sedang minum kopi sambil berdiri dan membaca koran. Anaknya tidak saja menegur, tapi juga mengatakan bagaimana seharusnya (tidak boleh makan dan minum sambil berdiri), tapi juga menjelaskakan konsekuensinya (berdosa). Ini membuat ayah dan ibunya terkejut atas pengetahuan anaknya, tapi juga karena anaknya menasihati orang tuanya, bukan sebaliknya sebagaimana yang lazim terjadi.

Menurut guru dan orang tua, karakter anak sholeh yang ditunjukkan anak dalam keseharian pada usia antara empat dan enam tahun, adalah mampu membiasakan mengerjakan shalat sesuai tuntunan Nabi Muhammad SAW; anak membiasakan berperilaku sopan dan baik, mengucapkan salam dan membalas salam, menggunakan kata-kata bil hikmah (kata-kata baik dan sesuai tuntunan nabi, anak mampu mengoreksi tindakan orang dewasa jika tidak sesuai dengan 
apa telah mereka pahami terkait perilaku berdasarkan tuntunan Hadits.

Hal ini sejalan dengan teori Bloom (1956:7) tentang ranah pendidikan yang dibagi atas 3 (tiga) domain yaitu kognitif, afektif dan psikomotorik. Menurut Bordieu (1985:11), perilaku manusia dapat berubah setelah adanya pembelajaran yang diperoleh melalui habitus, arena, dan modal. Bagi Muller (2006:215-217), habitus pada anak usia dini sangat dipengaruh oleh nilai anak atau orientasi yang diharapkan oleh orangtua, nilai anak/orientasi lembaga pendidikan dan nilai anak/orientasi lingkungan/masyarakat terhadap anak. Ketiga pilar (orang tua, lembaga, dan lingkungan) bersinergi dalam arena, yang dalam konteks ini, melalui proses enkulturasi nilai-nilai "keislamanan" yang dipadukan dengan kurikulum nasional PAUD, sebagai modal dalam upaya untuk mengantar anak usia dini menempuh pendidikan selanjutnya.

\section{Kesimpulan dan Rekomendasi}

TK Wihdatul Ummah telah berhasil mengemban misi utama Wahdah Islamiyah di bidang pendidikan, utamanya dalam pembinaan generasi muda sejak dini dengan pembinaan akidah, tauhid, iman dan amal sholeh.

Pembangunan karakter berdasarkan nilainilai "keislaman" menjadi orientasi utama yang dibudayakan TK Wihdatul Ummah kepada anak usia dini dengan tetap mengacu kepada Kurikulum Nasional PAUD. Dalam prakteknya, TK Wihdatul Ummah telah mampu membudayakan kurikulum "keislaman" yang berfokus pada dua kompetensi inti, yakni untuk mencintai Al-Qur'an dan Hadits dan mengamalkan nilai-nilai keislaman sebagai karakter anak sholeh. Pencapaian kompetensi untuk mencintai Al-Qur'an dan Hadits ditunjukkan dalam kegiatan-kegiatan kompetensi dasar, yakni: menghafalkan surahsurah pada juz 30 dan melafalkan Hadits-hadits Rasulullah, taddabur Al-Qur'an dan Hadits, mempelajari huruf hijaiyyah, dan mengenal ibadah praktis sesuai tuntunan Rasulullah. Sedangkan pencapaian nilai-nilai "keislaman" sebagai karakter anak sholeh, ditunjukkan dengan beradab islami dalam kehidupan seharihari, dan berperilaku mandiri yang islami.

Aspek-aspek capaian anak didik dalam pembelajaran di TK Wihdatul Ummah mencakup: kedisiplinan, kemandirian dan kepercayaan diri; kepercayaan dan kedekatan kepada guru; kemampuan bersosialisasi; kemampuan menghargai dan memahami orang lain; kemampuan memahami penghargaan (reward) dan hukuman (punishment); dan kemampuan mengamalkan nilai-nilai keislaman sebagai karakter anak sholeh(ah).

Berdasarkan perspektif emik (guru dan orang tua ), pencapaian pengamalan pembentukan karakter anak di TK Wihdatul Ummah, berfokus pada nilai-nilai agama (mengerjakan ibadah secara mandiri dan sesuai tuntunan, mengucapkan do'a dan zikir sebelum dan setelah beraktivitas) dan nilai-nilai moral (membiasakan diri berperilaku baik, sopan, jujur, suka memberi/menolong dan hormat ) serta nilai-nilai sosial emosional anak (kemandirian, rasa percaya diri mampu bersosialisasi, menghargai dam memahami orang lain, mengendalikan diri secara wajar, memahami aturan dan disiplin).

Selain itu, pengalaman orang tua dan guru terkait kemampuan anak dalam memahami Hadits dan adab islami yang dipraktekkan anak dalam lingkungan keluarga. Anak mampu mengoreksi tindakan orang dewasa jika tidak sesuai dengan adab islami (seperti adab makan dan minum, berkata yang baik, membiasakan mengucapkan salam dan mencium tangan, adab ketika azan). Dengan bersekolah di TK Wihdatul Ummah, bukan hanya anak didik yang berubah prilakunya, tapi orang tua juga menunjukkan perubahan yang signifikan (seperti mendalami agama melalui kajian-kajian Islam).

Temuan penelitian ini dapat menjadi rujukan bagi pemerintah melalui Direktorat 
Pendidikan Anak Usia Dini sebagai bahan masukan dalam penyusunan standar atau tingkat pencapaian perkembangan anak.

\section{Daftar Pustaka}

Abdullah, I. 2010. Konstruksi dan Reproduksi Kebudayaan. Yoyakarta: Pustaka Pelajar

Amini, Mukti. 2015. "Profil Keterlibatan Orang Tua Dalam Pendidikan Anak Usia TK". Jurnal IImiah Visi PPTK PAUDNI, 10 (1): 9-20.

Bloom, B. S.; Engelhart, M.D.; Furst, E.J.; Hill, W.H.; dan Krathwohl, D.R. 1956. Taxonomy of Educational Objectives: Handbook 1, Cognitive Domain. New York: David McKay.

Bourdieu, P. 1985. "The Forms of Capital", dalam Richardson, J.E. (ed.), Handbook of Theory of Research for the Sociology of Education. New York: Greenword Press, 46-58.

Harker, R., Mahar, C., dan Wilkes, C (ed). 1990. (Habitus $\times$ Modal $)+$ Ranah $=$ Praktik, Terj. oleh Pipit Mazier. Yogyakarta: Jalasutra.

Hodges, D. J. 2011. The Antropology of Education. New York (USA): Cognella.

Hunenengo, Novitasari. 2014. "Faktor-faktor yang mempengaruhi Perkembangan Sosial pada Anak Kelompok B PAUD Unggulan Mutiara Desa Dulamayo Kec Bongomene Kab Gorontalo".
Gorontalo: Fakultas Ilmu Pendidikan UN.

Jurdi, S. 2007. Sejarah Wahdah Islamiyah: Sebuah Geliat Ormas Islam di Era Transisi. Yogyakarta: Kreasi Wacana.

. 2015. Borjuasi dan Borjuasi Kultural Dalam mengukir Sejarah Peradaban. Makassar: Alaudin Press.

Kurniasari, ND. 2015. "Pola Pembelajarn dan Pengasuhan Pendidikan Anak Usia Dini di PAUD Madura". Komunikasi 9(2): 113-118.

Mansur. 2005. Pendidikan anak usia dini dalam Islam. Yogyakarta: Pustaka Pelajar.

Muller, J. 2006. Perkembangan Masyarakat Lintas-IImu. Jakarta: PT Gramedia Pustaka Utama.

Rolina, Nelva. 2004. PAUD Berbasis Pengembangan Karakter: Dasar Peningkatan Mutu Pendidikan Nasional. Yogyakarta: UNY.

Seda, F. S. 2012. "Kelas Menengah Indonesia: Gambaran Umum Konseptual", Prisma. LP3ES, 3(31):3-13.

Tilaar, H.A.R. 1999. Pendidikan, Kebudayaan dan Masyarakat Madani Indonesia. Bandung: PT. Remaja Rosda Karya.

Yusuf, F.; Aries,S., Rumanda.,Y., dan Maryati, S. 2015. Pedoman Pengelolaan Kelas PAUD. Jakarta: Diterbitkan oleh Direktorat Pendidikan Anak Usia Dini. 